\title{
Pengaruh Pengetahuan tentang Seksual, Dorongan Seksual dan Media Pornografi terhadap Perilaku Seksual Remaja Pranikah
}

\author{
Nurainih, ${ }^{1}$ Sobar Darmadja ${ }^{2}$ \\ ${ }^{1}$ Universitas Bhayangkara Jakarta Raya \\ ${ }^{2}$ Sekolah Tinggi Ilmu Kesehatan Indonesia Maju \\ Email : ${ }^{1}$ aini0331@yahoo.co.id, ${ }^{2}$ sobar2000@gmail.com
}

\begin{abstract}
Abstrak
Remaja merupakan salah satu tahapan pertumbuhan dan perkembangan dalam siklus kehidupan manusia. Perilaku seksual yang tidak sehat di kalangan remaja khususnya remaja yang belum menikah cenderung meningkat. Dengan terbukanya arus komunikasi dan informasi menyebabkan munculnya dorongan seksual yang mendorong keingintahuannya akan pengalaman seksual. Tujuan penelitian mengetahui pengaruh langsung dan tidak langsung serta besarannya antara pengetahuan tentang seksual, dorongan seksual dan media pornografi terhadap perilaku seksual remaja pranikah di Universitas Bhayangkara Jakarta RayaTahun 2013. Penelitian menggunakan desain cross sectional dan dilakukan di Universitas Bhayangkara Jakarta Raya dari Bulan Desember 2013. Jumlah sampel sebanyak 60 orang. Hasil uji pengetahuan terhadap perilaku seksual remaja menunjukkan ada pengaruh positif $18,86 \%$, dorongan seksual terhadap perilaku seksual remaja ada pengaruh positif $57,60 \%$ dan media pornografi terhadap perilaku seksual remaja ada pengaruh positif $28,01 \%$, sedangkan media pornografi terhadap dorongan seksual ada pengaruh sebesar 27,54\% dan pengetahuan terhadap dorongan seksual ada pengaruh sebesar 62,58\%. Dengan hasil penelitian ini diharapkan dapat memberi sumbangan pengetahuan yang benar dan dapat digunakan dalam meningkatkan pengetahuan terkait media pornografi yang dapat mempengaruhi remaja melakukan hubugan seksual diluar nikah, dengan demikian remaja dapat memilih dan memilah yang baik dan benar dalam pergaulan.
\end{abstract}

Kata Kunci : Perilaku Seksual Remaja, Pengetahuan, Pornografi.

\begin{abstract}
Teenagers are one of the stages of growth and development in the human life cycle. Unhealthy sexual behavior among adolescents, especially young unmarried tend to increase. By opening the flow of communication and information that led to the emergence of sexsual urges will encourage curiosity sexual experience. The research objective determine the effect of direct and indirect, and its magnitude between sexsual knowledge, sexsual drive and media pornography to teenage premarital sexual behavior at the University of Jakarta Bhayangkara Year 2013. The study used a cross sectional and conducted at the University of Bhayangkara Jakarta Raya from December 2013. Total sample of 60 people. Knowledge of test results to adolescent sexual behavior showed no positive effect 18,86\%, sexual urges towards adolescent sexual behavior was $57,60 \%$ and the positive influence of pornographic media on adolescent sexual behavior was a positive 28,01\%, while the media of pornography on sexual drive no influence of $27,54 \%$ and a knowledge of the sexual urge no influence of 62,58\%. With the results of this study are expected to contribute knowledge and can be used to increase knowledge related to pornographic media affect teen sexual relations outside marriage, so teens can select and sort the
\end{abstract}

Keywords: Sexual Behavior, Knowledge, Pornography. 


\section{Pendahuluan}

Remaja merupakan salah satu tahapan pertumbuhan dan perkembangan dalam siklus kehidupan manusia. Remaja merupakan fase pertumbuhan dan perkembangan ketika seseorang berada pada rentang usia 11-18 tahun ${ }^{1}$. Perilaku seksual yang tidak sehat di kalangan remaja khususnya remaja yang belum menikah cenderung meningkat. Hal ini terbukti dari beberapa hasil penelitian bahwa yang menunjukkan usia remaja ketika pertama kali mengadakan hubungan seksual aktif bervariasi antara usia 14-23 tahun dan usia terbanyak adalah antara 17-18 tahun. Perilaku seksual pada remaja dapat diwujudkan dalam tingkah laku yang bermacam-macam, mulai dari perasaan tertarik, berkencan, berpegangan tangan, mencium pipi, berpelukan, mencium bibir, memegang buah dada di atas baju, memegang buah dada di balik baju, memegang alat kelamin di atas baju, memegang alat kelamin di bawah baju, dan melakukan senggama $^{2}$. Perilaku hubungan seksual pranikah dapat menyebabkan kehamilan yang tidak diinginkan sehingga cenderung melakukan aborsi. Tingkat aborsi di Indonesia diperkirakan sekitar 2 sampai dengan 2,6 juta kasus pertahun, 30\% diantaranya dilakukan oleh penduduk berusia 15-24 tahun ${ }^{3}$. Aborsi yang dilakukan remaja mempunyai risiko yang lebih tinggi dibandingkan dengan dewasa, karena remaja kebanyakan melakukan aborsi yang tidak aman. Akibat lain dari hubungan seksual remaja adalah tingginya infeksi HIV/AIDS, berdasarkan data resmi secara kumulatif tercatat 21.770 kasus HIV/AIDS ${ }^{4}$. Setiap tahun terdapat sekitar 15 juta remaja berusia 15-19 tahun pernah melahirkan ${ }^{3}$.

Perilaku seseorang dipengaruhi oleh tiga faktor, yaitu faktor predisposisi, faktor pendukung, dan faktor pendorong. Menunjukkan bahwa faktor-faktor yang mempengaruhi perilaku seks pranikah remaja adalah hubungan orangtua remaja, tekanan negatif teman sebaya, pemahaman tingkat agama (religiusitas) dan eksposur media pornografi memiliki pengaruh yang signifikan, baik langsung maupun tidak langsung terhadap perilaku seksual pranikah remaja ${ }^{5}$. Makin baik hubungan orang tua dengan anak remajanya, makin rendah perilaku seksual pranikah remaja. Faktor-faktor yang mempengaruhi perilaku seksual pranikah pada remaja paling tinggi adalah hubungan antara orang tua dengan remaja, tekanan teman sebaya, pemahaman tingkat agama (religiusitas) dan eksposur media pornografi ${ }^{5}$. Penilaian 1038 remaja berumur 13-17 tahun terhadap hubungan di luar nikah adalah $16 \%$ dari remaja mengatakan sikap setuju dalam melakukan hubungan seks di luar nikah, sedang $43 \%$ mengatakan tidak setuju melakukan hubungan seks di luar nikah ${ }^{5}$. Kecenderungan perilaku seksual pra nikah di kalangan remaja semakin banyak terjadi, tercermin dari tingkat aborsi di kalangan remaja diperkirakan sekitar 700 ribu kasus per tahun atau sekitar 30\% dari seluruh kasus aborsi per tahun di Indonesia. Suatu penelitian yang pernah dilakukan BKKBN (Badan Kesejahteraan Keluarga Berencana Nasional) menyatakan bahwa perilaku seksual remaja belakangan ini memang mencemaskan. Persentase remaja laki-laki yang melakukan hubungan seksual adalah $34,9 \%$ dan perempuan yang pernah melakukan hubungan seksual sebelum menikah sebesar $24 \%$. Remaja di Jakarta yang pernah melakukan hubungan seks sebelum menikah ada sebanyak $42 \%{ }^{3}$. Data dari Universitas Bhayangkara Jakarta Raya Tahun 2013 menurut kepala Universitas Bhayangkara terdapat 35 orang mahasiswi perempuan dan 25 orang mahasiswa laki-laki dalam 1 kelas pembelajaran. Dari 62 mahasiswa/i yang kuliah dalam 1 kelas terdapat 3 orang mahasiswi yang lagi hamil diluar nikah dan 2 orang mahasiswi yang lagi cuti kerena menikah $^{6}$. Studi pendahuluan di Universitas Bhayangkara Jakarta Raya, didapatkan data hasil wawancara terhadap 10 mahasiswa, dari informasi yang diperoleh menyatakan 34\% mahasiswa tidak setuju terhadap sikap seks diluar nikah, sedangkan $46 \%$ mahasiswa setuju terhadap seks diluar nikah dan $20 \%$ mahasiswa menyatakan belum mengetahui tentang faktorfaktor yangat mempengaruhi remaja melakukan hubungan seksual pranikah. Selain itu peneliti juga mendapatkan informasi dari salah satu mahasiswi putri mengatakan pernah melakukan hubungan seksual diluar nikah, dikarenakan alasan sebagai pembuktian cinta pada pacarnya. Disamping itu juga dari keterangan 8 mahasiswa/i mengatakan sebagian mereka memperoleh informasi seksual melalui media masa (HP, TV dan Majalah Dewasa). Dari keterangan 8 dari 10 mahasiswa/i juga mengatakan dengan 
mudahnya memperoleh informasi seksual, membuat remaja ingin melakukan hubungan seksual diluar nikah dengan pacar maupun sahabat dan teman pergaulan, walaupun ada perasaan takut didalam diri mereka. Berdasarkan hal tersebut diatas maka sangat diperlukan adanya pengetahuan, sikap, dan faktor-faktor lain tentang seksual yang benar bagi remaja. Pengetahuan mengenai perilaku seksual pranikah tentu saja bertujuan untuk lebih memahami dampak dari perilaku seksual pranikah baik secara fisik sampai dampak sosial. Sehingga dapat memberikan pemahaman lebih dalam mengenai perilaku seksual pranikah sebelum melakukan lebih jauh.

\section{Metode}

Penelitian ini adalah survey analitik menggunakan pendekatan kuantitatif dengan metode cross sectional atau potong lintang dengan mengunakan pendekatan kuantitatif karena penelitian ini memberikan kemudahan dalam mengidentifikasi hubungan situasi dalam waktu yang singkat dan desain penelitian ini juga dapat digunakan untuk mengembangkan hipotesa untuk penelitian selanjutnya. Lokasi penelitian ini dilakukan di Universitas Bhayangkara Jakarta Raya di Jl. Darmawangsa I No.1 Kebayoran Jakarta Selatan. Proses penelitan yang penulis laksanakan pada bulan Desember 2012. Sedangkan populasi dalam penelitian ini adalah seluruh Mahasiswa Universitas Bhayangkara Jakarta Raya Mahasiswa Tingkat 1 dengan jumlah 60 Mahasiswa. Metode pengukuran baik untuk variable eksogen maupun endogen, yang dipakai pada penelitian ini menggunakan skala interval. Metode pengukuran yang dipakai dalam penelitian ini menggunakan skala interval, sedangkan teknik pengukuran menggunakan Semantik diffrensial. Yang mempunyai skala 5 poin. Pada skala ini sifat positif diberi nilai paling besar dan sifat negative diberi nilai paling kecil tetap dipertahankan, demikian juga prinsip menggabungkan positif-negatif dan negativepositif. Alasan pemilihan skala defferensial

semantic karena menurut Ridwan tahun 2012, yaitu berisikan serangkaian karakteristik bipolar (dua kutub).
Cara pengumpulan data primer yang digunakan dalam penelitian ini melalui alat bantu (instrument) berupa angket/pertanyaan diperoleh melalui penyebaran kuesioner, yang dilakukan oleh peneliti kepada responden yang telah sesuai dengan kriteria yang ditetapkan, Alat bantu (instrument) berupa angket/pertanyaan yang mengandung masingmasing indikator dalam 4 variabel. Adapun variabel yang dimaksud mencakup variabel yang terdiri dari tentang lingkungan social, media pornografi, dorongan seksual dan perilaku seksual remaja. Seluruh data yang sudah terkumpul dalam penelitian selanjutnya akan diolah dengan mengunakan program statistik berbasis komputer yaitu SPSS dan PLS (partial least square). Pendekatan PLS adalah distribution free (tidak mengasumsikan data berdistribusi tertentu, dapat berupa nominal, kategori, ordinal, interval, ratio). Model formalnya mendefinisikan variabel laten dan linier agregat dari indikatorindikatornya. SmartPLS mempunyai keunggulan tersendiri diantaranya data tidak harus berdistribusi normal multivariate dan ukuran sampel tidak harus besar ${ }^{7}$. Dalam penelitian ini analisa pengaruh pengetahuan tentang seksual menopause, kecemasan seksual menopause dan perilaku seksual Remaja di Universitas Bhayangkara Jakarta Raya Tahun 2013, menggunakan model Structural Equition Model (SEM) dengan SmartPLS. Pendugaan parameter (estimasi) didalam PLS dikategorikan sebagai berikut:

1. Weight estimate untuk menciptakan skor variabel laten didapat berdasarkan bagaimana inner model (model struktural yang menghubungkan antar variabel laten) dan outer model (model pengukuran yaitu hubungan antara indikator dengan konstruknya) dispensifikasi. Hasilnya adalah residual variance dari variabel dependen (keduanya variabel laten dan indikator) diminimumkan. Inner Model atau Model Struktural menggambarkan hubungan antar variabel laten berdasarkan pada substantive theory. Perancangan model Struktural hubungan antar variabel laten didasarkan pada rumusan masalah atau hipotesis penelitian. Sedangkan outer

model atau model pengukuran mendefisikan bagaimana setiap blok indikator berhubungan dengan variabel 
latennya. Perancangan Model Pengukuran menentukan sifat indikator dari masingmasing variabel laten, apakah refleksif atau formatif berdasarkan definisi operasional variabel.

2. Path estimate (estimasi jalur) yang menghubungkan variabel laten dan antara variabel laten dan blok indikatornya (loading).

3. Estimasi means dan lokasi parameter (nilai konstanta regresi) untuk indikator dan variabel laten.

\section{Hasil}

Data penelitian dikumpulkan dari 60 responden berkaitan dengan pengetahuan, dorongan seksual, media pornografi dan perilaku seksual remaja pranikah, penilaian diisi oleh responden untuk menilai pengaruh pengetahuan, dorongan seksual dan media pornografi terhadap perilaku seksual remaja. Berdasarkan hasil penelitian, dari 60 responden, 31 orang $(51,7 \%)$ adalah berjenis kelamin laki-laki, dan sebanyak 33 orang $(48,3 \%)$ dengan jenis kelamin perempuan. Dilihat dari usia responden, terdapat 37 $(61,7 \%)$ responden dengan umur $>18$ tahun dan responden dengan umur 16-18 tahun sebanyak 23 (38,3\%). Dilihat dari Agama, sebagian besar responden beragama Islam sebanyak $43(71,7 \%)$. Dilihat dari status orang tua responden terbanyak yaitu menikah $(86,7 \%)$ sebanyak 52 dan tempat tinggal responden terbanyak, terdapat $41 \quad(68,3 \%)$ responden tinggal di kost/kontrakan. Dari hasil penelitian diperoleh data pengetahuan responden dari distribusi skor hasil Pengetahuan terbesar 27 direntang 34-39. Fakta ini menunjukkan bahwa responden sebagian besar dengan pengetahuan yang sudah cukup tinggi. Dari data dorongan seksual responden menunjukkan bahwa dari distribusi skor dorongan Seksual frekuensi terbesar 16 direntang 29-34. Fakta ini menunjukkan bahwa sebagian besar responden dengan dorongan seksual yang cukup tinggi. Dari media pornografi, diperoleh skor rentangan Media Pornografi terbanyak antara rentang 15-18 yaitu sebanyak 13 responden.
Fakta ini menunjukkan bahwa data media pornografi cukup tinggi. Dari perilaku seksual responden, diperoleh skor rentangan perilaku seksual remaja terbanyak antara rentang 47-50 yaitu sebanyak 14 responden. Fakta ini menunjukkan bahwa perilaku seksual responden cukup tinggi. Berdasarkan hasil pengujian $\mathrm{Chi}$ Square dengan tingkat signifikansi $\alpha=5 \%$ menunjukkan nilai Pvalue $>0,05$. Hal ini menunjukkan bahwa variabel penelitian tidak dipengaruhi oleh karakteristik responden.

Inner model atau disebut juga inner relation menggambarkan hubungan antar variabel laten berdasarkan pada teori. Model struktural dievaluasi dengan melihat nilai $R$ square untuk konstruk laten dependen, Stobe Geisser Q-Square Test untuk Prediktive Relevance dan Uji $t$, serta signifikansi dan koefisien parameter jalur struktural. Perubahan nilai $R$-square dapat digunakan untuk menilai pengaruh variabel laten independen terhadap variabel dependen. Dari gambar 1 dibawah menunjukkan bahwa konstruk variabel Pengetahuan diukur dengan 1 indikator. Demikian juga dengan Dorongan Seksual dan Media Pornografi diukur dengan 3 dan 2 indikator dan Perilaku Seksual Remaja juga diukur dengan 3 indikator. Selanjutnya dilakukan uji Outer Model atau model pengukuran dengan indikator reflektif dievaluasi dengan Convergent Validity dan Discriminant Validity dari indikatornya dan Convosite Reability atau blok indikator. Outer model sering disebut outer relation atau measurement model yang didefinisikan bagaimana setiap blok indikator berhubungan dengan variabel. Suatu indikator reflektif dinyatakan valid jika mempunyai loading factor diatas 0,5 terhadap konstruk yang dituju berdasarkan pada substantive content-nya dengan melihat signifikansi dari weight $(\mathrm{t}=$ 1,96). Output smartPLS untuk loading factor memberikan hasil sebagai berikut pada gambar 2. Berdasarkan hasil pengukuran tersebut, nilai bahwa loading factor untuk indikator DS1-DS3 mempunyai loading factor tertinggi terhadap variabel Dorongan Seksual daripada konstruk lain. 


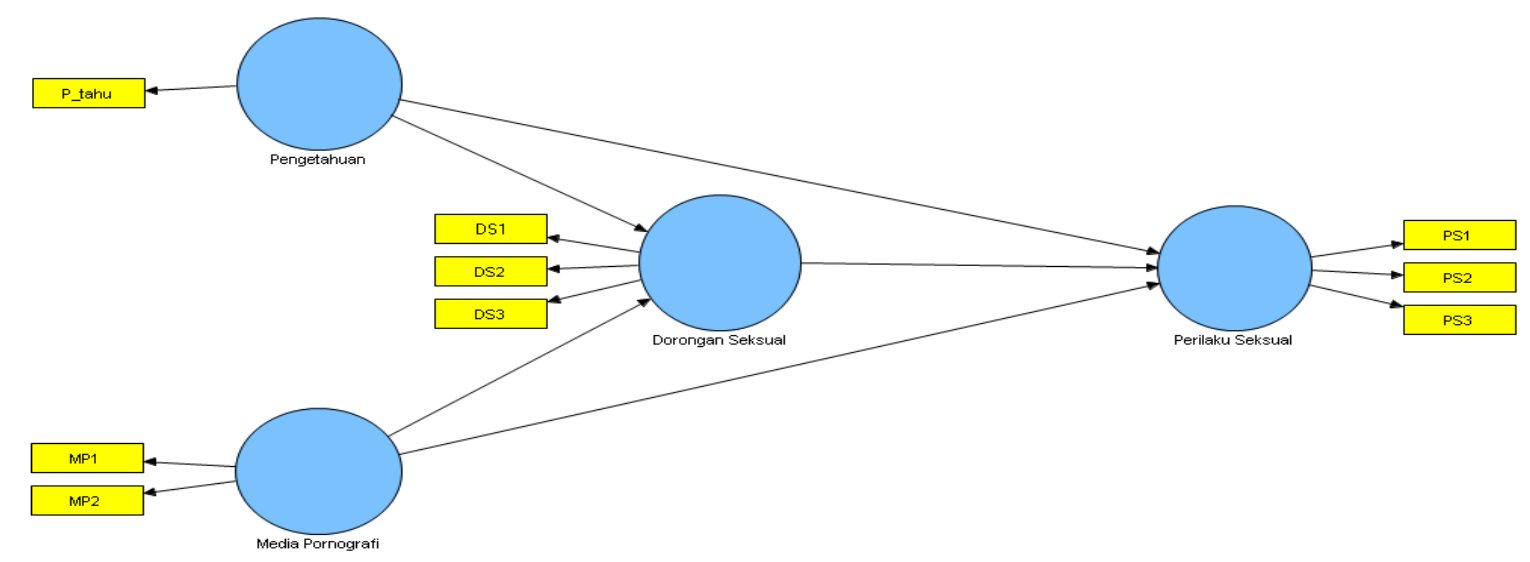

\section{Gambar 1}

Gambar model penelitian (model Struktural) mengenai pengaruh lasngsung dan tidak langsung variabel pengetahuan tentang seksual, dorongan seksual dan media pornografi terhadap perilaku seksual remaja pranikah di Universitas Bhayangkara Jakarta Raya Tahun 2013

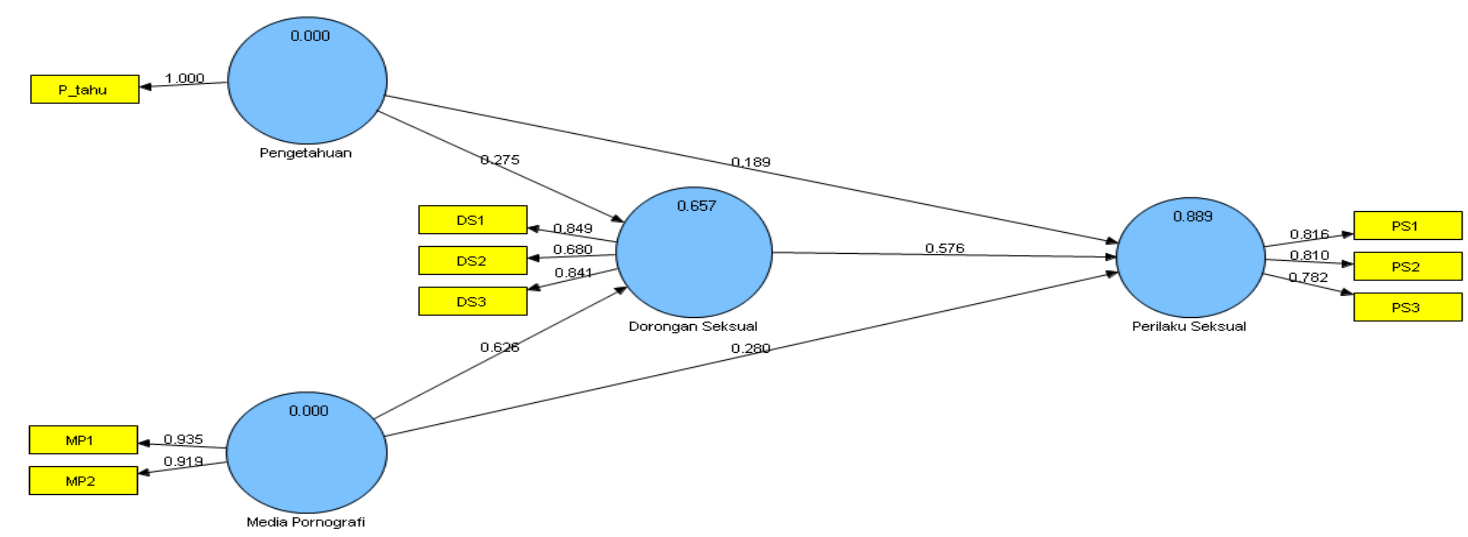

Gambar 2

Gambar model penelitian (setelah dilakukan bootstraping) pengaruh lasngsung dan tidakn langsung pengetahuan tentang seksual, dorongan seksual dan media pornografi terhadap perilaku seksual remaja pranikah di Universitas Bhayangkara Jakarta Raya Tahun 2013

Tabel 1. Nilai R Square

\begin{tabular}{|l|l|}
\hline & R Square \\
\hline Dorongan Seksual & 0.656910 \\
\hline Media Pornografi & \\
\hline Pengetahuan & \\
\hline Perilaku Seksual & 0.889069 \\
\hline
\end{tabular}

Sumber: smartPLS 2.0 diolah 2013 
Tabel 2. Nilai Path Coefficient/Rho

\begin{tabular}{|c|c|c|c|c|}
\hline & $\begin{array}{l}\text { Original Sample } \\
\text { (Rho) }\end{array}$ & $\begin{array}{l}\text { T Statistics } \\
(>196)\end{array}$ & $\mathbf{H}_{\mathbf{0}}$ & Kesimpulan \\
\hline $\begin{array}{l}\text { Dorongan Seksual } \quad-> \\
\text { Perilaku Seksual }\end{array}$ & 0.575995 & 7.954990 & Ditolak & $\begin{array}{l}\text { Berpengaruh positif } \text { dan } \\
\text { signifikan }\end{array}$ \\
\hline $\begin{array}{l}\text { Media Pornografi } \quad-> \\
\text { Dorongan Seksual }\end{array}$ & 0.625764 & 8.398474 & Ditolak & $\begin{array}{l}\text { Berpengaruh positif dan } \\
\text { signifikan }\end{array}$ \\
\hline $\begin{array}{l}\text { Media Pornografi } \quad-> \\
\text { Perilaku Seksual }\end{array}$ & 0.280046 & 3.814567 & Ditolak & positif dan \\
\hline $\begin{array}{ll}\text { Pengetahuan } & -> \\
\text { Dorongan Seksual } & \end{array}$ & 0.275420 & 3.336005 & Ditolak & $\begin{array}{l}\text { Berpengaruh positif } \text { dan } \\
\text { signifikan }\end{array}$ \\
\hline $\begin{array}{l}\text { Pengetahuan } \rightarrow \text { Perilaku } \\
\text { Seksual }\end{array}$ & 0.188563 & 3.617480 & Ditolak & positif dan \\
\hline
\end{tabular}

Sumber: smartPLS 2.0 diolah 2013

Dari tabel 1 dapat dilihat bahwa Pengetahuan, Media Pornografi dan Dorongan Seksual mampu menjelaskan terhadap variabel Perilaku Seksual Remaja sebesar 88,91\% dan sisanya sebesar $11,09 \%$ dijelaskan oleh variabel lain diluar dari yang diteliti. Dan Variabel Pengetahuan dan Media Pornografi juga mampu menjelaskan terhadap variabel Dorongan Seksual sebesar 65,69\% dan sisanya sebesar 34,31\% dijelaskan oleh variabel lain diluar dari yang diteliti. Selanjutnya dilakukan uji hipotesis dapat dilihat melalui tabel berikut ini. Dari tabel diatas dapat dijelaskan bahwa Dorongan Seksual berpengaruh positif terhadap Perilaku Seksual Remaja. Hasil ujinya terhadap koefisien parameter antara Dorongan Seksual terhadap Perilaku Seksual Remaja menunjukkan ada pengaruh positif 0,575995, sedangkan nilai $\mathrm{T}$ statistik sebesar 7,954990 dan signifikan pada $\alpha=5 \%$. Nilai tersebut berada lebih dari $(1,96)$.

Kemudian pada tabel diatas dapat dijelaskan bahwa Media Pornografi berpengaruh positif terhadap Dorongan Seksual. Hasil ujinya terhadap koefisien parameter antara Media Pornografi terhadap Dorongan Seksual menunjukkan ada pengaruh positif 0,625764 , sedangkan nilai $\mathrm{T}$ statistik sebesar 8,398474 dan signifikan pada $\alpha=5 \%$. Nilai tersebut berada lebih dari $(1,96)$.

Lalu pada tabel diatas dapat dijelaskan bahwa Media Pornografi berpengaruh positif terhadap Perilaku Seksual Remaja. Hasil ujinya terhadap koefisien parameter antara Media Pornografi terhadap Perilaku Seksual Remaja menunjukkan ada pengaruh positif 0,280046 , sedangkan nilai $\mathrm{T}$ statistik sebesar 3,814567 dan signifikan pada $\alpha=5 \%$. Nilai tersebut berada lebih dari $(1,96)$.

Kemudian pada tabel diatas dapat dijelaskan bahwa Pengetahuan berpengaruh positif terhadap Dorongan Seksual. Hasil ujinya terhadap koefisien parameter antara Pengetahuan terhadap Dorongan Seksual menunjukkan ada pengaruh positif 0,275420 , sedangkan nilai $\mathrm{T}$ statistik sebesar 3,336005 dan signifikan pada $\alpha=5 \%$. Nilai tersebut berada lebih dari $(1,96)$.Begitu juga dengan variabel pengetahuan berpengaruh positif terhadap Perilaku Seksual Remaja. Hasil ujinya terhadap koefisien parameter antara Pengetahuan terhadap Perilaku Seksual Remaja menunjukkan ada pengaruh positif 0,188563 , sedangkan nilai $\mathrm{T}$ statistik sebesar 3,617480 dan signifikan pada $\alpha=5 \%$. Nilai tersebut berada lebih dari $(1,96)$.

Dari tabel 2 menyatakan bahwa Pengetahuan berpengaruh secara langsung dan tidak langsung terhadap Perilaku Seksual Remaja. Hasil uji koefisien parameter antara Pengetahuan terhadap Perilaku Seksual Remaja menunjukkan terdapat pengaruh langsung sebesar 13,19\% terhadap Perilaku Seksual Remaja. sedangkan untuk pengaruh tidak langsung Pengetahuan terhadap Perilaku Seksual Remaja melalui Dorongan Seksual 
Tabel 3. Persentase Pengaruh Antar Variabel terhadap Variabel Perilaku Seksual Remaja dan

Dorongan Seksual pada model

\begin{tabular}{|c|c|c|c|c|c|c|c|}
\hline Variabel & \begin{tabular}{|c|} 
Laten \\
Variabel \\
Correlation \\
\end{tabular} & Direct Rho & Inderect Rho & Total & $\begin{array}{c}\text { Direct } \\
\%\end{array}$ & $\begin{array}{c}\text { Inderect } \\
\%\end{array}$ & Total \% \\
\hline Pengetahuan & 0.699266 & 0.188563 & 0.131856 & 0.320419 & 13.19 & 0.00 & 13.19 \\
\hline $\begin{array}{c}\text { Dorongan } \\
\text { Seksual } \\
\end{array}$ & 0.910429 & 0.575995 & 0.524403 & 1.100398 & 52.44 & 0.00 & 52.44 \\
\hline $\begin{array}{c}\text { Media } \\
\text { Pornografi }\end{array}$ & 0.831335 & 0.280046 & 0.232812 & 0.512858 & 23.28 & 0.00 & 23.28 \\
\hline Pengetahuan & 0.619392 & 0.275420 & 0.17059 & 0.44601 & 0.00 & 17.06 & 17.06 \\
\hline $\begin{array}{c}\text { Media } \\
\text { Pornografi }\end{array}$ & 0.777158 & 0.625764 & 0.48632 & 1.112084 & 0.00 & 48.64 & 48.64 \\
\hline \multicolumn{5}{|c|}{ Total } & 88.91 & 65.7 & 154.61 \\
\hline
\end{tabular}

Sumber: smartPLS 2.0 diolah 2013

didapat dengan mengalikan koefisien jalur (Pengetahuan $\rightarrow$ Dorongan Seksual) dengan koefisien jalur (Dorongan Seksual $\rightarrow$ Perilaku Seksual Remaja) dan dijumlahkan dengan koefisien jalur (Pengetahuan $\rightarrow$ Perilaku Seksual Remaja) sehingga mendapatkan nilai 0.17059 atau sebesar $17.06 \%$. Media Pornografi berpengaruh secara langsung dan tidak langsung terhadap Perilaku Seksual Remaja. Hasil uji koefisien parameter antara Media Pornografi terhadap Perilaku Seksual Remaja menunjukkan terdapat pengaruh langsung sebesar $23.28 \%$ terhadap Perilaku

Seksual Remaja. sedangkan untuk pengaruh tidak langsung Media Pornografi terhadap Perilaku Seksual Remaja melalui Dorongan Seksual didapat dengan mengalikan koefisien jalur (Media Pornografi $\rightarrow$ Dorongan Seksual) dengan koefisien jalur (Dorongan Seksual $\rightarrow$ Perilaku Seksual Remaja) dan dijumlahkan dengan koefisien jalur (Media Pornografi $\rightarrow$ Perilaku Seksual Remaja) sehingga mendapatkan nilai 0.48632 atau sebesar $48.64 \%$.Sehingga nilai dari masing-masing pengaruh langsung variabel laten independent tersebut apabila secara bersama-sama menunjukkan kesesuaian dengan nilai Square atau dengan kata lain hal ini menyatakan bahwa variabel Pengetahuan, Dorongan Seksual dan Media Pornografi mampu menjelaskan variabel Perilaku Seksual Remaja sebesar $(13,19 \%+$ $52,44 \%+23,28 \%)=88,91 \%$.

\section{Pembahasan \\ Pengaruh langsung Pengetahuan terhadap Perilaku Seksual Remaja Pranikah}

Berdasarkan hasil penelitian bahwa pengetahuan berpengaruh positif terhadap perilaku seksual remaja. Hasil ujinya terhadap koefisien parameter antara pengetahuan terhadap perilaku seksual remaja menunjukkan ada pengaruh positif 0,188563 , sedangkan nilai $\mathrm{T}$ statistik sebesar 3,617480 dan signifikan pada $\alpha=5 \%$. Nilai tersebut berada lebih dari $(1,96)$.

Pengetahuan seksualitas menurut Wildan tahun (2003) merupakan pengetahuan yang menyangkut cara seseorang bersikap atau bertingkah laku yang sehat, bertanggung jawab serta tahu apa yang dilakukannya dan apa akibat bagi dirinya, pasangannya dan masyarakat sehingga dapat membahagiakan dirinya juga dapat memenuhi kehidupan seksualnya ${ }^{8}$.

Di barat kenyatannya yang terjadi justru sebaliknya. Tingkat pendidikan cenderung significant dan positif terhadapa perilaku seks pranikah. Hal ini ada kaitannya dengan pola berfikir mereka, dimana mereka memiliki pengetahuan yang lebih baik tentang perilaku seks yang bertanggung jawab, misalnya tentang penggunaan alat pencggah kehamilan. Hal ini menyebabkan mereka merasa dapat menyalurkan hasrat seksual walaupun belum menikah, tetapi dengan cara yang lebih bertanggung jawab ${ }^{2}$. Mereka yang terjerumus

dalam seks bebas tersebut sesungguhnya hanya didorong rasa ingin tahu dan cobacoba. Berdasarkan hasil penelitian hubungan tingkat pengetahuan dan sikap di SMAN 2 Karanganyar dari 56 responden mayoritas cenderung memiliki tingkat pengetahuan baik 
4 orang dan melakukan sikap cukup sebanyak 23 orang. Penelitian ini mendapatkan hasil melalui $\mathrm{z}$ hitung $(1,9)$ dengan nilai korelasi Kendall Tau $=0,173$. Kemudian hasil z hitung dibandingkan dengan $\mathrm{z}$ tabel $(0,596)$ untuk taraf kesalahan $5 \%(0,05)$. Karena harga $\mathrm{z}$ hitung > z tabel, maka Ho ditolak sedangkan $\mathrm{Ha}$ diterima (1,9>0,596) sehingga hasil perolehan dinyatakan signifikan yang berarti hubungan positif antara tingkat pengetahuan remaja tentang kesehatan reproduksi dengan sikap terhadap seks pra nikah sebesar 1,9. Sikap yang dimiliki seseorang dipengaruhi oleh tingkat pengetahuan. Dalam hal ini tanggung jawab orang tua untuk memberikan pendidikan seks, menanamkan nilai moral dan agama kepada remaja harus diperjelas dan ditingkatkan. Lingkungan yang tidak mendukung (kurang baik) akan memberikan pengaruh pada seseorang dan cenderuh kearah negatif seperti hubungan seks diluar nikah. Dalam teori diperjelas bahwa proses mengadopsi perilaku terjadi secara berurutan dari mulai kesadaran dimana remaja tersebut menyadari dan mengetahui terlebih dahulu terhadap stimulus kemudian inters atau merasa tertarik terhadap stimulus, dilanjutkan dengan evaluation (menimbang), trial (mencoba) dan adoption (mengadopsi) ${ }^{9}$.

Menurut Penulis Pengetahuan berpengaruh terhadap Perilaku Seksual Remaja Pranikah, hal ini sesuai dengan teori yang menyatakan dengan pengetahuan yang kurang baik maka seorang remaja cenderung untuk bertindak dan bertingkah laku yang kurang baik juga. Untuk meningkatkan pengetahuan remaja agar dapat berprilaku yang baik dan benar dapat dengan diberikan pendidikan kesehatan dan penyuluhanpenyuluhan kesehatan, agar remaja yang dalam pertumbuhannya yang labil dapat memilih dan memilah mana perilaku yang baik dan mana perilaku yang kurang baik dalam pergaulan.

\section{Pengaruh langsung Dorongan Seksual Terhadap Perilaku Seksual Remaja Pranikah}

Berdasarkan hasil penelitian bahwa dorongan Seksual berpengaruh positif terhadap Perilaku Seksual Remaja. Hasil ujinya terhadap koefisien parameter antara Dorongan Seksual terhadap Perilaku Seksual Remaja menunjukkan ada pengaruh positif 0,575995, sedangkan nilai $\mathrm{T}$ statistik sebesar
7,954990 dan signifikan pada $\alpha=5 \%$. Nilai tersebut berada lebih dari $(1,96)$.

Perilaku seksual adalah segala tingkah laku yang didorong oleh hasrat seksual, baik dengan lawan jenisnya maupun dengan lawan jenis. Bentuk-bentuk tingkah laku ini bisa bermacam-macam, mulai dari perasaan tertarik sampai tingkah laku berkencan, bercumbu, dan bersenggama ${ }^{2}$.

Hubungan seksual pranikah berkaitan erat dengan harga diri. Menurut Tambunan tahun 2001, harga diri mengandung arti suatu hasil penilaian individu terhadap dirinya yang diungkapkan dalam sikap-sikap yang dapat bersifat positif atau negatif. Keputusan untuk melakukan hubungan seks tersebut tidak dengan konsekuensi yang kecil, terutama untuk remaja wanita. Perasaan-perasaan negatif seperti hilangnya keperawanan, rasa malu, rasa bersalah, rasa berdosa, kotor, takut, khawatir dan lainnya akan timbul setelah mereka melakukan hubungan seks pranikah ${ }^{10}$.

Berdasarkan komponen harga diri yang terdapat pada subjek menurut Felker dalam Churaisin tahun 2004, mengenai harga diri, maka didapatkan hasil wawancara bahwa subjek memiliki harga diri yang rendah. Dintara ketiga kompenen tersebut adalah perasaan diterima (felling of belonging), perasaan mampu (felling of competence) dan perasaan berharga (felling of worth $)^{11}$.

Perasaan diterima (felling of belonging) yaitu perasaan individu bahwa dirinya merupakan bagian dari suatu kelompok dan dirinya diterima seperti dihargai oleh anggota kelompoknya. Kelompok ini dapat berupa keluarga, kelompok teman sebaya, atau kelompok apapun. Individu akan memiliki penilaian yang positif tentang dirinya apabila individu tersebut merasa diterima dan menjadi bagian dalam kelompoknya. Namun individu akan memiliki penilaian negatif tentang dirinya bila mengalami perasaan tidak diterima, misalnya perasaan seseorang pada saat menjadi anggota kelompok suatu kelompok tertentu.

Hal ini dapat dilihat bahwa walaupun subjek melakukan hubungan seks pranikah, subjek merasa dirinya tetap diterima oleh lingkungan dan keluarganya karena subjek merasa lingkungan dan keluarganya tidak mengetahui kalau subjek pernah melakukan hubungan seks pranikah. Namun berbeda halnya terhadap lawan jenis. Setelah subjek melakukan hubungan seks pranikah, subjek 
tidak dapat diterima apa adanya dengan pasangan barunya. Karena setelah subjek terbuka dengan pasangannya bahwa dirinya pernah melakukan hubungan seks agar pasangan subjek dapat menerima subjek apa adanya. Tapi pada kenyataannya pasangan subjek tidak ada yang bisa menerima subjek apa adanya dikarenakan pasangannya menuntut untuk melakukan hubungan seks dengan subjek.

\section{Perasaan mampu (fellinof}

competence), yaitu perasaan dan keyakinan individu akan kemampuan yang ada pada dirinya sendiri dalam mencapai suatu hasil yang diharapkan, misalnya perasaan seseorang pada saat mengalami keberhasilan atau kegagalan.

Hal ini dapat dilihat Setelah subjek terbuka dengan pasangannya, subjek merasa pasangannya tidak ada yang dapat menerima subjek apa adanya. hal itu membuat subjek merasa tidak mampu atau tidak berani lagi terbuka dengan pasangannya dan setelah subjek melakukan hubungan seks pranikah, dalam menjalin hubungan dengan lawan jenis subjek kurang mampu dan cenderung belum sesuai dengan harapan subjek dikarenakan subjek merasa dirinya selalu gagal dan tidak mampu untuk mempertahankan hubungan dengan pasangannya.

Menurut Scanzoni dan Szanconi dalam Hadi tahun 2006, hubungan seks pranikah yang dilakukan pria dan wanita yang belum terikat perkawinan, dimana nantinya mereka akan menikah satu sama lain atau masingmasing akan menikah dengan orang lain. Jadi tidak hanya terbatas pada orang yang berpacaran saja. Hubungan seksual ini umumnya terjadi diantara mereka yang telah meningkat remaja menuju dewasa. Hal ini sangat mungkin terjadi mengingat pada saat seseorang memasuki masa remaja mulai timbul dorongan-dorongan seksual didalam dirinya. Apalagi pada masa ini minat mereka dalam membina hubungannya terfokus pada lawan jenis ${ }^{12}$.

Saat ini kecenderungan pola masyarakat tentang seks bebas mengalami banyak perubahan. Perubahan-perubahan itu terjadi dikarenakan iklim sosial saat ini yang membuat pola pergaulan anak muda sekarang makin permisif. Dulu orang menganggap kalau seks dilakukan setelah menikah. Sekarang perilaku seks pranikah terkesan sebagai suatu yang lumrah ${ }^{15}$. Hal-hal ini yang menyebabkan penurunan batas usia yang melakukan hubungan seksual semakin menurun. Ini bisa dilihat dari beberapa hasil penelitian yang menunjukkan adanya penurunan batas usia hubungan seksual pertama kali yaitu $18 \%$ responden di Jakarta berhubungan seks pertama dibawah usia 18 tahun dan usia termuda 13 tahun (Iskandar, 2000) dan remaja di Manado yang sudah aktif secara seksual, melakukan hubungan seks pertama pada usia dibawah 16 tahun. Sebanyak 56,8\% pada remaja pria dan $33,3 \%$ pada remaja putri ${ }^{2}$.

Dilihat dari beberapa hal yang menjadi dasar remaja melakukan hubungan seksual tersebut. Remaja pria dan wanita memiliki alasan-alasan yang berbeda, pada remaja putri kebanyakan memberikan alasan seperti ingin menunjukan rasa cinta, takut ditinggalkan, dipaksa oleh pacar, agar dicintai, tidak mau dianggap tidak laku karena masih perawan dan lain-lain. Keputusan untuk melakukan hubungan seks tersebut tidak dengan konsekuensi yang kecil, remaja yang telah melakukan hubungan seks harus juga memikirkan resiko yang dihadapinya nanti seperti hamil diluar nikah dan terkena penyakit kelamin. Pendapat ini didukung pula oleh Santrock dalam Sarwono tahun 2004, alasan-alasan mengapa remaja berhubungan seks antara lain, dipaksa (Wanita 61\% dan Pria 23\%), merasa sudah siap (Wanita $51 \%$ dan Pria 59\%), Butuh dicintai (Wanita 45\% dan Pria 23\%) dan takut diejek teman karena masih gadis atau perjaka (wanita $38 \%$ dan Pria $43 \%)^{2}$.

Menurut Peneliti Dorongan Seksual berpengaruh terhadap perilaku Seksual Remaja Pranikah, hal ini dikarenakan dorongan seksual dimasa remaja memang sangat sulit untuk di hindari, tergantung pada pembawaan dari dalam diri remaj itu sendiri. Kebanyakan remaja tidak sadar akan perilaku yang dapat menjerumuskan dirinya pada halhal yang negatif terkait perilaku seksual dimasa remaja. Bimbingan dan pantauan orang tua sangat dibutuhkan bagi perkembangan remaja. Apalagi remaja yang cenderung bergaul dengan lawan jenis yang dapat terjerumus dalam pergaulan bebas dan tidak menutup kemungkinan untuk berhubungan seksual dengan lawan jenis maupun dengan sesama jenis. Disampin itu diperlukan adanya kesadaran pada remaja itu sendir untuk mengontrol dorongan seksual, 
misalnya dengan melakukan hal-hal yang fositif seperti berolahraga dan belajar.

\section{Pengaruh langsung Media Pornografi Terhadap Perilaku Seksual Remaja Pranikah}

Berdasarkan hasil penelitian bahwa media pornografi berpengaruh positif terhadap perilaku seksual remaja. hasil ujinya terhadap koefisien parameter antara media pornografi terhadap perilaku seksual remaja menunjukkan ada pengaruh positif 0,280046, sedangkan nilai $\mathrm{T}$ statistik sebesar 3,814567 dan signifikan pada $\alpha=5 \%$. Nilai tersebut berada lebih dari $(1,96)$.

Menurut Benokraitis tahun 2003, yaitu karena orang tua cenderung jarang berbicara tentang seks, remaja sering kali mendapatkan informasi yang salah tentang seks dari apa yang disebut popular culture, seperti televisi, film, majalah dan novel. Hal ini juga didukung oleh Sarwono tahun 2004, kecendrungan pelanggaran makin meningkat oleh karena adanya penyebaran informasi dan rangsangan seksual melalui media massa yang dengan adanya teknologi canggih (video, kaset, fotocopy, satelit, vcd, telepon genggam, internet dan lain-lain) menjadi tidak terbendung lagi. Remaja yang sedang dalam periode rasa ingin tahu dan ingin mencoba, akan meniru yang dilihat atau didengarkannya dari media massa khususnya karena mereka pada umumnya belum pernah mengetahi masalah seksual secara lengkap dari orang tuanya ${ }^{2}$.

Menurut peneliti Media Pornografi berpengaruh terhadap Perilaku Seksual Remaja Prnaikah, remaja dengan perkembangan dunia yang modern ini, dengan berkembangnya teknologi membuat remaja sangat mudah memperoleh informasi baik yang fositif maupun negatif negatif. Kecenderungan remaja jaman sekarang rentan untuk lebih menyukai informasi yang bersifat negatif karena untuk memuaskan nafsu duniawi sesaat, tanpa mempertimbangkan resiko dan dosa dikemudian hari. Untuk menghindari remaja dari keterpaparan media pornografi diperlukan adanya pengawasan orang tua yang sangat ketat untuk memantau semua kegiatan dan aktifitas yang dilakukan remaja saat bergaul dengan teman-temannya.

\section{Pengaruh Media Pornografi terhadap} Dorongan Seksual Remaja Pranikah
Berdasarkan hasil penelitian bahwa Media Pornografi berpengaruh positif terhadap Dorongan Seksual. Hasil ujinya terhadap koefisien parameter antara Media Pornografi terhadap Dorongan Seksual menunjukkan ada pengaruh positif 0,625764 , sedangkan nilai $\mathrm{T}$ statistik sebesar 8,398474 dan signifikan pada $\alpha=5 \%$. Nilai tersebut berada lebih dari $(1,96)$.

Pada zaman sekarang ini, kehidupan seksual dikalangan remaja sudah lebih bebas dibandingkan dahulu. Hal ini bisa kita rasakan di kota-kota besar di Indonesia, terbukanya saluran informasi seputar seks yang bebas beredar di masyarakat pada saat ini melalui media-media seperti televisi, koran, radio dan internet boleh jadi mendorong remaja melakukan hubungan seks pranikah. Pendapat ini didukung dalam penelitian Wijaya dalam Anissa tahun 2009, bahwa 51,5\% (48,5\% responden pria dan $6 \%$ responden wanita ) yang berusia 13-15 tahun, 67,3\% berusia 1617 tahun dan $26,7 \%$ berusia diatas 18 tahun menyatakan dari hasil penelitian ini terungkap $7 \%$ dari responden melakukan hubungan seks pranikah. $100 \%$ dari mereka yang melakukan hubungan seks pranikah ini mengaku mendapatkan gagasan untuk

melakukan hubungan seks dari ved porno yang mereka liat, $73 \%$ dari teman, $66 \%$ dari internet, $47 \%$ dari media cetak seperti koran atau majalah ${ }^{13}$.

Menurut Peneliti Media Pornografi berpengaruh juga terhadap Dorongan Seksual Remaja Pranikah, dengan kemajuan dan modernisasi teknologi membawa pengaruh bagi keluarga, termasuk remaja dalam keluarga. Hal ini diakarenakan desakan dalam pergaulan antar teman, baik karena gengsigengsian, dengan kemajuan teknologi yang pesat saat ini, jika kurangnya pemahaman yang tepat bagi remaja dapat menyebabkan keinginan yang kuat bagi remaja untuk mengetahui hal-hal yang negatif, karena remaja lebih cenderung untuk lebih asyik belajar hal-hal yang negatif dan sering mengabaikan nilai-nilai moral dimasyarakat. Teknologi yang baik sangat diperlukan misalnya dengan diberikan penyuluhan terkait bahaya menonton film porno di internet karena dapat menyebabkan dorongan seks remaja dalam berbuat asusila, karena tidak dapat menahan gejolak seksual yang diketahuinya. 


\section{Kesimpulan}

Dari hasil penelitian ini dapat disimpulkan pengaruh langsung pengetahuan tentang seksual, dorongan seksual dan media pornografi terhadap perilaku seksual remaja pranikah sebesar 88,91\%, dengan pengetahuan yang negatif, penggunaan media pornografi dan dorongan seksual yang tinggi akan menyebabkan remaja berperilaku seksual yang lebih besar. Disamping itu, variabel pengetahuan dan media pornografi berpengaruh secara tidak langsung terhadap dorongan seksual Seksual Remaja Pranikah sebesar 65,70\%, dengan kurangnya pemahaman remaja terkait seksual pranikah dan penggunaan media pornografi yang tinggi akan menyebabkan remaja cenderung mempunyai dorongan seksual yang tinggi.

Dari hasil penelitian ini juga diperoleh nilai Prediktif Relevance ( $Q$ Square) sebesar 96,20\%, yang dapat disimpulkan bahwa Model Hasil Analisis dapat menjelaskan 96,20\% keragaman data dan mampu mengkaji fenomena yang dipakai dalam penelitian, sedangkan $3,80 \%$ dijelaskan variabel lain yang tidak ada dalam penelitian ini.

\section{Saran}

Dengan hasil penelitian ini, diharapkan dapat digunakan sebagai dasar masukan dalam memperoleh keadaan kesehatan remaja di Universitas Bhayangkara, dengan demikian pihak Universitas Bhayangkara dapat memberikan Pelayanan Kesehatan yang optimal dalam bentuk Pendidikan Kesehatan yang tepat dan efektif terkait dampak, resiko dan pentingnya remaja mengetahui arti dan konsekuensi yang dapat dialami jika melakukan hubungan seksual diluar nikah.

\section{Daftar Pustaka}

1. Hurlock E. Psikologi Perkembangan Suatu Pendekatan Sepanjang Rentang Kehidupan. Erlangga; Jakarta. 2009

2. Sarwono S.W. Psikologi Remaja. Jakarta; PT Raja Grafindo Persada. 2010
3. BKKBN. STARH., USAID. Pubertas dan Kematangan Seksual Pada Remaja. Pamflet Informasi Kesehatan Reproduksi Remaja; Edisi 2. 2003.

4. Departemen Kesehatan RI. Kebijakan Dan Strategi Nasional Kesehatan Reproduksi. Jakarta : 2005.

5. Soetjiningsih. Tumbuh Kembang Remaja dan Permasalahannya. Jakarta; CV. Sagung Seto. 2007.

6. Profil Universitas Bhayangkara Tahun 2011

7. Ghozali I. Structural Equation Modeling Teori, Konsep dan Aplikasi dengan Program Lisrel 8.80. BP UNDIP. Semarang: 2008.

8. Nurhayati. Hubungan Antara Sikap Remaja Terhadap Bentuk-Bentuk Perilaku Seksual Dengan Perilaku Seksualnya Selama Menjalani Tahap Berpacaran. FK Psikologi Universitas Padjajaran. [SKRIPSI]. 2008.

9. Notoatmodjo S. Ilmu Perilaku Kesehatan. Jakarta; Rineka Cipta; 2003.

10. Notoatmodjo S. Promosi Kesehatan dan Ilmu Perilaku. Jakarta; Rineka Cipta; 2007.

11. Tambunan. Harga diri remaja. 2001. Diakses tanggal 5 maret 2013 dari Http://www.epsikologi.com/remaja/240901.1 $\underline{\mathrm{htm}}$.

12. Churaisin S. E. Hubungan antara harga diri dengan kenakalan remaja. Skripsi.Edisi ke 1. Depok; Fakultas Psikologi Universitas Indonesia; 2004.

13. Hadi, M, H. Perilaku seks pranikah pada remaja. [Skripsi]. (Tidak Diterbitkan). Depok.Fakultas Psikologi Univeristas Gunadarma. 2006.

14. Anissa K. Making love sama dengan cinta itu seks. Cetakan 1. Yogyakarta: Garasi; 2009.

15. Prasetyaningrum J. Hubungan Antara Pengetahuan Seksualitas dan Kualitas Komunikasi Orang Tua-Anak dengan Perilaku Seksual Pranikah. 2006. Diambil dari: eprints.ums.ac.id (diakses pada tanggal 20 Januari 2013) 